\title{
RESEARCH ARTICLES ОРИГИНАЛЬНЫЕ СТАТЬИ \\ SPECIES COMPOSITION AND COMMUNITY STRUCTURE OF SMALL MAMMALS IN PARAPOLSKY DOL (KORYAK STATE NATURE RESERVE, KAMCHATKA)
}

\author{
Alyona Yu. Levykh, Vitaliy V. Panin \\ Tyumen State University, Russia \\ e-mail:aljurlev@mail.ru,paninvv@mail.ru
}

Received: 16.06.2018. Revised: 11.04.2019. Accepted: 13.04.2019.

\begin{abstract}
Parapolsky Dol is one of the largest wetlands of world importance. However, there is only fragmentary information about the species composition and structure of animal communities in this area, due to its inaccessibility. This fact determines the relevance of studying small mammals as an indicator group in Parapolsky Dol. The article deals with the results of a research on the fauna and small mammal communities of Parapolsky Dol (Koryak State Nature Reserve), carried out from 25 August to 15 September 2017. The study area included the shore of Lake Talovskoye, the floodplains of the River Tylakrylvayam and the River Ichiginnyvayams. During the period of 2735 trap-nights and 144 cylinder-nights we captured 5 small mammal species: Myodes rutilus, M. rufocanus, Sorex isodon, S. caecutiens and Ochotona hyperborea. The surveyed habitats ranged from the maximum to the minimum abundance of small mammals: the floodplain of the River Ichiginnyvayam - 10.9 individuals/100 trap-nights, 8.0 individuals /100 cylinder-nights; the shore of Lake Talovskoye -3.48 individuals/100 trap-nights; the floodplain of the River Tylakrylvayam - 1.43 individuals/100 trap-nights, 2.53 individuals/100 cylinder-nights. The largest number of species (4) was captured in the habitats with woody vegetation and berry beds. The results of the capture by snap traps revealed the tendency of $M$. rutilus and $S$. rufocanus to dominate in most habitats. The results of the capture by cylinders show that $S$. caecutiens is dominant in the surveyed open habitats. All studied communities are characterised by low diversity indices, average values of dominance index, sufficiently high evenness and low sustainability. One can explain such structure of small mammal communities by the zonal and climatic conditions of the territory. The diversity/evenness structure in all the communities corresponds to that of the natural habitats in central, southern Kamchatka and Siberia. The small mammal communities on the shore of Lake Talovskoye and the floodplain of the River Ichiginnyvayam are characterised by high diversity indices, while the communities of the floodplain of the River Tylakrylvayam are distinguished by a high evenness index. We observed animal reproduction in the small mammal communities (pregnant and lactating females of different age groups were captured). The largest number of pregnant females and embryos, the highest values of reproductive success, indices of conservation and the generalised indices of well-being were identified in the small mammal communities in cedar and birch ribbon forests on the shore of Lake Talovskoye and in floodplain of the River Tylakrylvayam. In the plant associations Ledum decumbens + Vaccinium uliginosum - Cladonia sp. + Cladina sp., and Ledum decumbens + Vaccinium uliginosum - Sphagnum sp. we did not observe any reproduction. The material of this research work supplement the data on the fauna and population structure of small mammals in Parapolsky Dol.
\end{abstract}

Key words: Beringian forest-tundra, common shrews, relative abundance, small land rodents, species diversity

\section{Introduction}

Under the influence of unprecedented human activities that transform natural ecosystems (Kryazhimskii et al., 2001) and large-scale climatic changes (Ovaskainen et al., 2013; Gashev et al., 2017), biological monitoring is a priority in assessing and predicting the state of ecosystems. Both in Russia and abroad, small mammals are part of the long-term and large-scale studies of ecosystem changes. Small land rodents and insectivores, due to their ecological and biological features, are sensitive indicators of habitat changes (Martell \&
Pearson, 1978; Istomin, 2009; Myers et al., 2009; Zakharov et al., 2011; Hope et al., 2017), convenient model objects for studying the mechanisms of biocoenosis stability (Agulova et al., 2016; Kataev, 2017), micro-evolutionary processes (Litvinov, 2008) and for making decisions on nature management (Smith et \& Zollner, 2001; Sullivan et al., 2017). Long-term studies of small mammals have been carried out on special sites in Protected Areas (Vinogradov, 2009; Bobretsov \& Simakin, 2015; Bobretsov et al., 2015; Kataev, 2015, 2016; Akpatou et al., 2018) and research centres (Dokuchaev, 
1997, 2012; Henttonen \& Wallgren, 2001; Deitloff et al., 2010; Ivanter \& Moiseeva, 2015). The studies allowed to examine some regular influences of climatic variations on populations and communities (Aars \& Ims, 2002; Bobretsov \& Simakin, 2015; Bobretsov et al., 2015; Kataev, 2016, 2017), to trace the long-term effects of human activities on ecosystems (Kataev, 2016, 2017), and to show the importance of studying populations on the periphery of the species' habitat (Moskvitina et al., 2000; Ivanter \& Moiseeva, 2015).

Populations and small mammal communities on the Kamchatka Peninsula are of interest not only from the point of view of assessing and predicting the state of the unique ecosystems and studying micro-evolutionary processes in populations at the margin of their habitat, but also for reconstructing the history of modern fauna development with regard to the existence of Bering land in the past (Dokuchaev, 1997, 2012; Weksler et al., 2010).

At the same time, there is only fragmentary information on the species composition and relative abundance of small mammals in specially protected natural areas of the Kamchatka Peninsula, including the territory of Koryak State Nature Reserve, because of their inaccessibility. In the survey of land vertebrates of eastern Kamchat$\mathrm{ka}$, Averin (2013) indicated the presence of three small mammal species in the fauna of northeastern Kamchatka - Myodes rutilus Pallas, 1779, Myodes rufocanus Sundevall, 1846, Microtus oeconomus Pallas, 1776, without specifying their abundance. In his summary report on the Kamchatka fauna, Nikanorov (2000) gave the data of taxonomic composition, relative abundance and habitat distribution of 14 species of small insectivores, harelike animals and rodents of the Koryak Highland, Penzhinsky Ridge and adjacent territories, without exact geo-referencing. Only the recent publication by Kazansky \& Sedash (2015) provided information on the species composition, habitat distribution and quantitative estimates of small mammal abundance in the floodplain of the River Ichiginnyvayam (Koryak State Nature Reserve), obtained during one field season.

Our aim was to study the species composition, abundance, habitat distribution, structure and sustainability of small mammal communities in the Protected Area Parapolsky Dol. The research work was performed as part of an integrated preliminary study of Parapolsky Dol ecosystems, the results of which will serve as the basis for environmental conservation planning in this area.

\section{Material and Methods}

The material includes the results of a small mammal census on the territory of Parapolsky Dol within the borders of the cluster site in Koryak Nature Reserve (60.975-61.775 N, 164.000-166.125 E). The study area belongs to the largest wetland complex of the Koryak district, included on the list of Ramsar wetlands of global importance and is part of the Beringian shrub (forest-tundra) region (Fig. 1).

The field research was carried out from 25 August to 15 September 2017 on three sites: 1) the shore of Lake Talovskoye (1235 trap-nights); 2) the territory of Parapolsky Dol adjacent to the left bank of the River Tylakrylvayam, about 20 $\mathrm{km}$ west of the Amethyst mine (750 trap-nights, 79 cylinder-nights); 3) the territory of Parapolsky Dol adjacent to the left bank of the River Ichiginnyvayam, $12 \mathrm{~km}$ north of the Amethyst mine (550 trap-nights, 125 cylinder-nights).

We carried out the census of small mammals in habitats (biotopes) characterised by certain plant associations formed under ecologically equivalent environmental conditions. The following plant species and genera determine the phytocoenoses of the study area: Pinus pumila (Pall.) Regel, Betula middendorffii Trautv. \& C.A. Mey., Betula exilis Sukacz., Salix pulchra Cham., Salix schwerinii E.L. Wolf, Salix udensis Trautv. \& C.A. Mey., Chosenia arbutifolia Pall., Populus suaveolens Fisch. (tree layer); Ledum decumbens Small., Vaccinium uliginosum L., Vaccinium vitis-idaea L., Empetrum nigrum L., Eriophorum polystachyon L., Carex bigelowii Torr. ex Schwein., Carex chordorrhiza L.f., Carex gynocrates Wormsk (grass and shrub layer); Aulacomnium palustre (Hedw.) Schwägr, Dicranum majus Turner, Sphagnum sp., Cladonia sp., Cladina sp. (moss and lichen layer).

Animals were captured in such plant associations as 1) the shore of Lake Talovskoye: Pinus pumila + Betula middendorffii $(\mathrm{Pp}+\mathrm{Bm})$; Betula exilis - Ledum decumbens + Vaccinium uliginosum - Aulacomnium palustre + Dicranum majus (Be-Ld+Vu-Ap+Dm); Eriophorum polystachyon + Carex bigelowii $(\mathrm{Ep}+\mathrm{Cb})$; Pinus pumilapurum (Ppp); 2) floodplain of the River Tylakrylvayam: $\mathrm{Pp}+\mathrm{Bm}$, Salix pulchra - Eriophorum polystachyon + Carex bigelowii (Sp$\mathrm{Ep}+\mathrm{Cb}) ;$ Ledum decumbens + Vaccinium uliginosum - Cladonia sp. + Cladina sp. ( $\mathrm{Ld}+\mathrm{Vu}-\mathrm{C}+\mathrm{C}) ;$ Ledum decumbens + Vaccinium uliginosum - Sphagnum sp. ( $\mathrm{Ld}+\mathrm{Vu}-\mathrm{S}) ; \mathrm{Ep}+\mathrm{Cb}$; Carex chordorrhiza + Carex gynocrates - Sphagnum sp. (Cc+Cg-S); 3) floodplain of the River Ichiginnyvayam: Chosenia arbutifolia + Populus suaveolens - Salix schwerinii + Salix 
udensis (Cha+Ps-Ss+Su); $\mathrm{Ld}+\mathrm{Vu}-\mathrm{C}+\mathrm{C}$; $\mathrm{Ld}+\mathrm{Vu}-\mathrm{S}$; Betula middendorffii - Sphagnum sp. (Bm-S). We singled out the plant associations on the basis of the dominant-edificatory approach. Phytocoenoses with the same set of layers and the same dominant species, similar in their overall species composition and structure, were related to one association. In the names of plant associations, the species belonging to the same layer are connected with the $\langle+\rangle\rangle$ sign, the species from different layers are connected with the «-»» sign, according to the generally accepted methodical approach (Prokopiev, 2003). More information about the vegetation on the shore of Lake Talovskoye and adjacent territories can be found in Neshataev et al. (2017) and Beldiman et al. (2017).

We captured animals by snap traps, placed in lines of 25-100 pieces at a distance of 5-7 $\mathrm{m}$ from each other within the same type of habitat. We used pieces of bread soaked in unrefined vegetable oil as bait. Every morning the traps were checked. Three days later they were moved to another place. In addition, the animals were captured by 50 -metre-long pitfall traps and 50-metre-long fences, with cylinders installed every $10 \mathrm{~m}$ (Karaseva et al., 2008). 0.5 litre plastic cups were used as cylinders. The pitfall traps and cylinders were periodically cleaned of in- sects, amphibians and debris. The survey took 2735 trap-nights and 144 cylinder-nights. We found no living animals in the traps and cylinders.

The species were determined by the features of the external structure, structure of teeth and skull (Yudin, 1971; Pavlinov, 2002). We determined the relative age by the presence or absence of the thymus (thymus gland), tooth abrasion and the size of the ridges on the skull bones. Relative abundance of small mammals in general and individual species was defined in terms of 100 trap-nights or 100 cylinder-nights.

We examined the captured animals by the method of morphophysiological indicators (Schwartz et al., 1968; Cadieux et al., 2015). Their sex and the number of embryos in female species were identified by cameral treatment. A number of dark placental spots or yellow spots of pregnancy in the uterine horns were found in females. On this basis we calculated the proportion of pregnant females (UBS), the number of embryos per pregnant female (EMS), the proportion of resorbed embryos (URE) and the integral reproductive success rate (URZ), expressed as a percentage of the number of young ones that 100 females could potentially produce per generation under the given conditions (Gashev, 2000):

$U R Z=\{[U B S \times 100((E M S \times 100(100-U R E \times 100)) / 100)] /[E M S \times 100]\} \times 100$

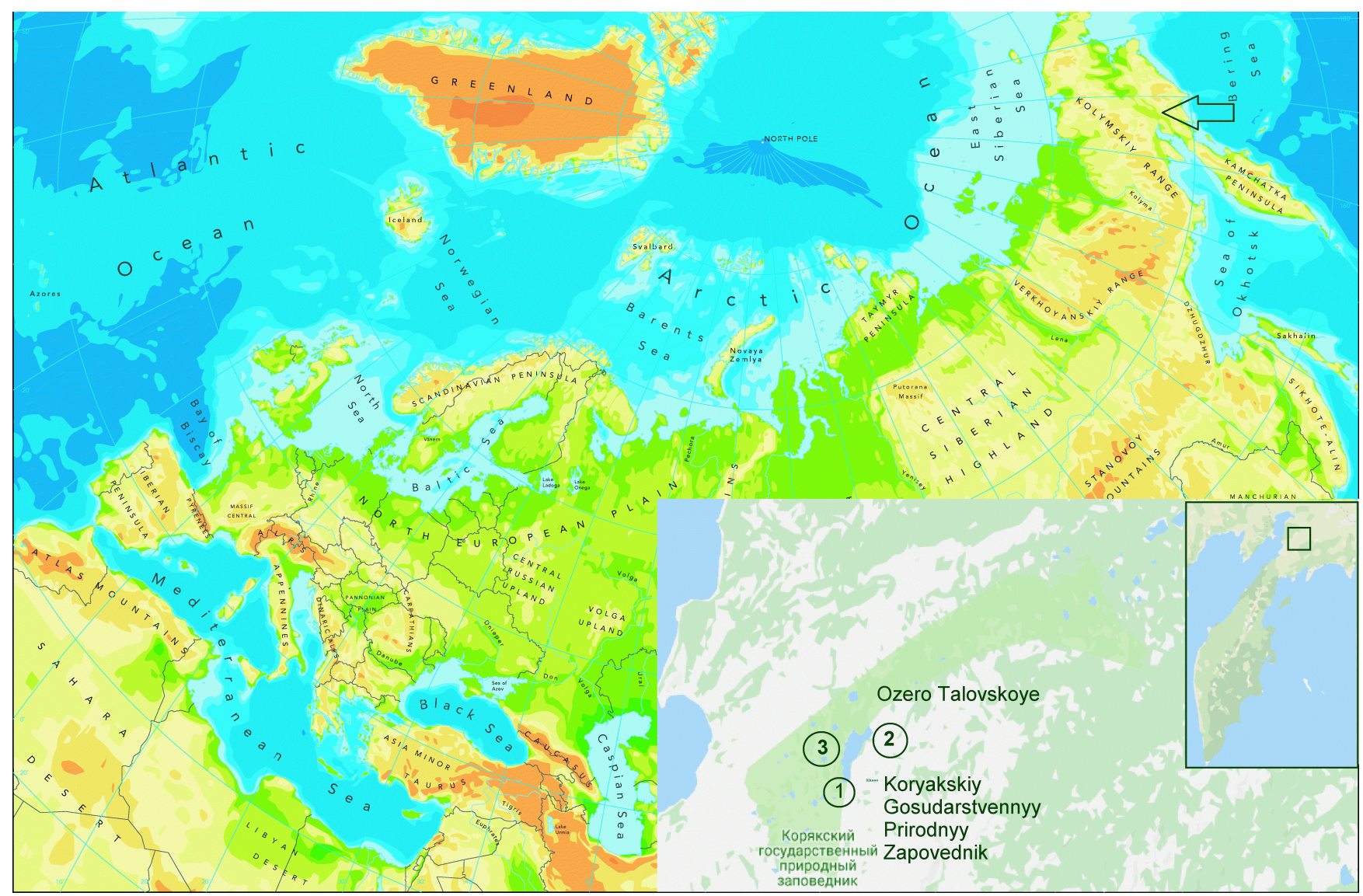

Fig. 1. The study area and collecting ground: 1) the shore of Lake Talovskoye; 2) the floodplain of the the River Ichiginnyvayam; 3) floodplain of the River Tylakrylvayam. 
The conservation index (IKV) was calculated by summing the numbers of females and wintering animals. The conservation of females is associated with their territoriality, whereas the conservation of wintering animals ensues from their advantage over young ones in competition for the most favourable areas.

We used the method of diversity indices to assess the structure of communities (Odum, 1986; Begon et al., 1989; Gashev, 2000). In order to assess the state of communities, the indices of resistance, elastic and general sustainability were calculated, based on the indices of diversity and the coefficients reflecting the physical and geographical features of a natural area and the stage of successive development of an ecosystem (Gashev, 2000). Following Gashev (2000), we treat resistant sustainability as the thermodynamic property of a system to resist the action of external forces trying to change its condition. Elastic sustainability is the ability of a system to return to its original state after the external forces cease. General sustainability (U) is the sum of elastic and resistant sustainability:

$$
\mathrm{U}=0.09 \mathrm{e}(\mathrm{D}(2 \mathrm{G}+3 \mathrm{~T}) / \mathrm{G})+0.9 \mathrm{D}(1+\mathrm{K} / \mathrm{R}),
$$

where the first summand is elastic sustainability (UU), the second is resistant sustainability (UR); $\mathrm{e}=2.718$ is the base of natural logarithm;

$\mathrm{D}=1-\Sigma(\mathrm{ni} / \mathrm{N})$ is Simpson's index of species diversity, $\mathrm{R}=(\mathrm{V}-1) / \lg \mathrm{N}$ is Margalef's species richness index, $\mathrm{V}$ is the number of species, $\mathrm{N}$ is the total number of specimens, $\mathrm{T}$ is the stage of ecosystem succession (a pioneer community with $0<\mathrm{T}<0.2$, a young community with $0.2<\mathrm{T}<0.3$ $\mathrm{mm}$, a transient community with $0.3<\mathrm{T}<0.5$, a mature community with $0.5<\mathrm{T}<0.9$ and a climax community with $\mathrm{T}=1$ ), $\mathrm{K}$ is the ratio of «viscosity» of the medium, $G$ is the ratio of «elasticity» of the medium (the latter two indicators defined for the forest-tundra zone, both $\mathrm{K}=3.5$ and $\mathrm{G}=0.75$ (Gashev, 2000, 2001; Gashev et al., 2015).

For an integral assessment of the state of the community we used the generalised index of community well-being (SSS), which is obtained by summing the indices of general sustainability (U), conservation (IKV), anthropogenic adaptability (IAA) and reproductive success (URZ):

\section{$\mathrm{SSS}=\mathrm{U}+0.1 \mathrm{IKV}+0.01 \mathrm{IAA}+0.01 \mathrm{URZ}$.}

The index of anthropogenic adaptability is an integral characteristic of the community, reflecting the ratio of different environmental groups in relation to people, its value equals 1.11 in all the studied communities. The algorithm for calculating the value is described in the monograph by Gashev (2000).

For inter-sample comparisons we calculated the arithmetic mean of the character (M), the arithmetic mean error $(\mathrm{m})$, the variance $\left(\sigma^{2}\right)$ and the coefficient of variation $(\mathrm{CV})$. Statistical comparisons were made by using Student $(\mathrm{t})$ and Fisher (F) significance tests (Ivanter \& Korosov, 2013). The differences were considered statistically significant if the actual value of the criterion exceeded the table value with $\mathrm{p} \leq 0.05$. Abbreviations used in the text are explained in the Appendix.

\section{Species composition}

\section{Results}

We captured a total of 120 individuals of five small mammal species in Parapolsky Dol: Insectivora - two individuals of Sorex isodon, 33 individuals of $S$. caecutiens; Rodentia - 67 individuals of Myodes rutilus, 16 individuals of M. rufocanus; Lagomorpha - two individuals of Ochotona hyperborea Pallas, 1811.

Ochotona hyperborea is a stenotopic species, captured in its typical habitat called «kurumnik», an open stony place overgrown with Siberian dwarf pine (Ppp) on the shores of Lake Talovskoye.

Sorex isodon, a widespread species in Kamchatka, was not numerous in the catches; it was captured only in the floodplain of the River Ichiginnyvayam (Table 1 ).

We captured the largest number of species (4) in kurumnik on the shore of Lake Talovskoye, overgrown with dwarf pine (Ppp) and adjoining the plant association $\mathrm{Ld}+\mathrm{Vu}-\mathrm{S}$. The diversity of the micro-habitats in the area creates prerequisites for coexistence of a larger number of species (Table 1). Four species were captured in the habitats with a predominance of woody vegetation $\mathrm{Cha}+\mathrm{Ps}-\mathrm{Ss}+\mathrm{Su}, \mathrm{Bm}-\mathrm{S}$ in the floodplain of the River Ichiginnyvayam. The confinement of most species to the habitats with forest vegetation is due to the good protective and feeding capacity of those habitats. Four species were also captured in open habitats with shrubby vegetation $-\mathrm{Ld}+\mathrm{Vu}-\mathrm{C}+\mathrm{C}$ and $\mathrm{Ld}+\mathrm{Vu}-\mathrm{S}$ in the floodplain of the River Ichiginnyvayam. This fact can be explained by the fruiting of berry bushes and good food provision during the survey period. In $100 \%$ of the opened stomachs of Myodes rutilus and M. rufocanus the fruit of $V$. uliginosum, $V$. vitis-idaea were found along with the seeds of $P$. pumila. 
Table 1. Relative abundance of small mammal species on the surveyed sites in Parapolsky Dol

\begin{tabular}{|c|c|c|c|c|c|c|c|c|c|c|c|}
\hline \multicolumn{4}{|c|}{ Lake Talovskoye shore } & \multicolumn{3}{|c|}{ River Tylakrylvayam floodplain } & \multicolumn{5}{|c|}{ River Ichiginnyvayam floodplain } \\
\hline $\begin{array}{l}\tilde{E} \\
\text { p } \\
\text { a } \\
\text { \& }\end{array}$ & $\stackrel{2}{2}$ & 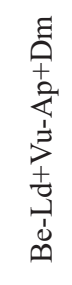 & $\Sigma$ & 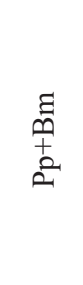 & 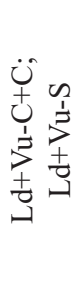 & $\Sigma$ & 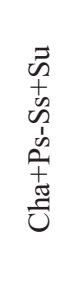 & 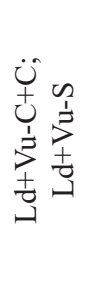 & 足 & $\sum_{\Sigma}^{*}$ & 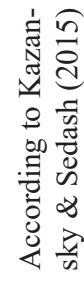 \\
\hline \multicolumn{12}{|c|}{ General abundance } \\
\hline 3.62 & 4.53 & 3.75 & 3.97 & 5.0 & 2.0 & 3.5 & 6.67 & 11.43 & 18.0 & 12.03 & 13.59 \\
\hline \multicolumn{12}{|c|}{ Myodes rutilus } \\
\hline 2.29 & 3.02 & 1.88 & 2.4 & 3.0 & 0.5 & 1.75 & 1.33 & 8.0 & $\frac{12.0}{4.44}$ & 7.11 & 5.14 \\
\hline \multicolumn{12}{|c|}{ Myodes rufocanus } \\
\hline 0.95 & 0.38 & 0.62 & 0.65 & 0 & 0 & 0 & 0.67 & 1.14 & 4.0 & 1.94 & 4.04 \\
\hline \multicolumn{12}{|c|}{ Ochotona hyperborea } \\
\hline 0 & 0.75 & 0 & - & 0 & 0 & 0 & 0 & 0 & 0 & 0 & - \\
\hline \multicolumn{12}{|c|}{ Sorex caecutiens } \\
\hline 0.38 & 0.38 & 1.25 & 0.67 & $\frac{2.0}{5.0}$ & 1.5 & 1.75 & 4,0 & $\frac{2.0}{7.5}$ & $\underline{2.0}$ & 2.67 & 3.43 \\
\hline \multicolumn{12}{|c|}{ Sorex isodon } \\
\hline 0 & 0 & 0 & 0 & 0 & 0 & 0 & 0.67 & 0.29 & 0 & 0.54 & 0.86 \\
\hline
\end{tabular}

Note: In four cases: Above the line - individuals/100 trap-nights, under the line - individuals/100 cylinder-nights.

* $\mathrm{M}$ is the arithmetic mean of abundance in the study area.

According to the results of the capture by snap traps, Myodes rutilus dominates in most biotopes, Sorex caecutiens and Myodes rufocanus co-dominate (Table 1). According to the results of counting by cylinders, the absolute dominant animal in the surveyed open habitats is $S$. caecutiens.

The general abundance of small mammals decreases in the following direction: the floodplain of the River Ichiginnyvayam - 10.9 individuals/100 trap-nights, 8.0 individuals/100 cylinder-nights; the shore of Lake Talovskoye - 3.48 individuals/100 trap-nights; the floodplain of the River Tylakrylvayam - 1.43 individuals/100 trap-nights, 2.53 individuals/100 cylinder-nights. No animals were captured in the wetland on the shore of Lake Talovskoye $(\mathrm{Ep}+\mathrm{Cb})$ and the floodplain of the River Tylakrylvayam $(\mathrm{Ep}+\mathrm{Cb} ; \mathrm{Cc}+\mathrm{Cg}-\mathrm{S})$. At the margin of $\mathrm{Sp}-\mathrm{Ep}+\mathrm{Cb}$ plant association in the floodplain of the River Ichiginnyvayam we captured one young male of $S$. caecutiens (3.33 individuals/100 cylinder-nights) in a pitfall trap, which can be considered a migrant.

The abundance of all small mammal species varies significantly in different biotopes and study areas. At the same time, no statistically significant differences were found in the average values of general abundance and the abundance of individual species, as well as the variation coefficients of these characteristics between different study areas. Significant differences were observed only in the vari- ance of the relative abundance of Myotes rufocanus, a type of habitat specialist, between the samples from the shore of Lake Talovskoye $\left(\sigma^{2}=0.082\right)$ and floodplains of the River Ichiginnyvayam $\left(\sigma^{2}=3.25\right)$ : $\mathrm{F}=39.63$, with $\mathrm{p}<0.05$. This can be explained by more uniform spatial distribution of $M$. rufocanus on the shore of Lake Talovskoye, because of a larger area of its habitat $(\mathrm{Pp}+\mathrm{Bm}$; $\mathrm{Ppp})$.

\section{Community structure}

All studied small mammal communities are characterised by low diversity indices, medium values of the dominance index, medium and high evenness (Table 2). The community on the shore of Lake Talovskoye is characterised by high indices of diversity and sustainability. We identified the highest indices of elastic, resistant and general sustainability in the community of small mammals in the plant association Be-Ld+Vu-Ap+Dm on the shore of Lake Talovskoye. This community is the most balanced in terms of the number of species, the number of individuals in each species, and, accordingly, the indices of diversity, dominance and evenness (Table 1, Table 2). However, statistically significant inter-sampling differences were revealed only by the arithmetic mean values of Shannon's diversity index $(\mathrm{H})$ (Talovskoye - Tylakrylvayam $-\mathrm{t}=5.37$, with $\mathrm{p}<0.01$; Tykryrylvayam - Ichiginnyvayam $-\mathrm{t}=3.94$, with $\mathrm{p}<0.05$ ) and Simpson's evenness index (E) (Talovskoye Tylakrylvayam $-\mathrm{t}=5.11$, with $\mathrm{p}<0.05$; Tylakraly- 
vayam - Ichiginnyvayam $-\mathrm{t}=4.57$, with $\mathrm{p}<0.05)$. The least numerous community of small mammals in the floodplain of the River Tylakrylvayam is characterised by the minimum value of Shannon's diversity index, but the maximum value of Simpson's evenness index (Table 2).

The values of diversity and sustainability indices of the small mammal communities in Parapolsky Dol are comparable to those of central (Geysernaya river valley, Uzon volcano caldera, the Death Valley) and southern (Lake Kurilskoye shore) Kamchatka (Table 3).

The lowest indices of species diversity and sustainability are characteristic for the communities in the most unstable habitats, such as the floodplain of the River Tylakrylvayam and the foot of the active volcano Kikhpinych (Table 2, Table 3). The indices of species diversity and evenness in the communities on the shore of Lake Talovskoye and the floodplain of the River Ichiginnyvayam slightly exceed the indices in southern habitats located in the zone of increased geothermal and volcanic ac- tivity (River Geysernaya valley and the foot of the Kikhpinich volcano). The fact indicates the destabilising effect of these factors on the surrounding ecosystems. The small mammal species from the shores of Lake Talovskoye have the highest rates of diversity and sustainability. Consequently, we can consider Lake Talovskoye as a key area for the study and preservation of biological diversity.

In relation to people, Myodes rutilus, M. rufocanus, Sorex isodon and S. caecutiens belong to the ecological group of neutrals, Ochotona hyperborea is related to the ecological group of anthropophobic animals (Gashev, 2000). The absence of anthropophiles, synanthropes and eusinantropes in the surveyed communities determines the low value of IAA $=1.11$.

\section{Demographic characteristics of communities}

During the census period (late summer - early autumn) in all study areas we observed a late reproduction of small mammals, with pregnant and lactating females of different age groups (Table 4).

Table 2. Diversity and sustainability indices of small mammal communities on the surveyed sites in Parapolsky Dol

\begin{tabular}{|c|c|c|c|c|c|c|c|c|c|c|}
\hline \multicolumn{4}{|c|}{ Lake Talovskoye shore } & \multicolumn{3}{|c|}{ Tylakrylvayam River floodplain } & \multicolumn{4}{|c|}{ River Ichiginnyvayam floodplain } \\
\hline $\begin{array}{l}\Xi \\
0 \\
+ \\
0 \\
0\end{array}$ & $\stackrel{2}{2}$ & 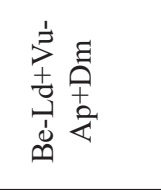 & $\begin{array}{l}\Xi \\
H \\
\dot{Z}\end{array}$ & 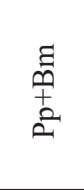 & 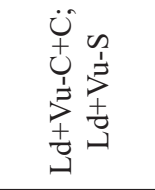 & $\begin{array}{l}\Xi \\
\text { I } \\
\Sigma\end{array}$ & 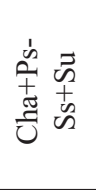 & 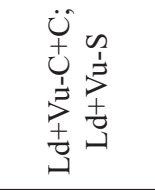 & $\begin{array}{l}\infty \\
\stackrel{1}{!} \\
\dot{D}\end{array}$ & $\begin{array}{l}\Xi \\
H \\
\dot{H}\end{array}$ \\
\hline \multicolumn{11}{|c|}{ Margalef's species richness index (R) } \\
\hline 1.56 & 2.78 & 1.85 & $2.06 \pm 0.37$ & 1.43 & 1.66 & $1.54 \pm 0.12$ & 3.00 & 1.86 & 2.10 & $2.32 \pm 0.35$ \\
\hline \multicolumn{11}{|c|}{ Shannon's diversity index (H) / Simpson's diversity index (D) } \\
\hline $\begin{array}{c}1.27 / \\
0.52\end{array}$ & $\begin{array}{c}1.42 / \\
0.52\end{array}$ & $1.44 / 0.61$ & $\begin{array}{c}1.38 \pm 0.05 / \\
0.55 \pm 0.03\end{array}$ & $\begin{array}{c}0.97 / \\
0.48\end{array}$ & $0.81 / 0.38$ & $\begin{array}{c}0.89 \pm 0.08 / \\
0.43 \pm 0.05\end{array}$ & $\begin{array}{c}1.57 / \\
0.58\end{array}$ & $1.31 / 0.49$ & $\begin{array}{l}1.22 / \\
0.49\end{array}$ & $\begin{array}{c}1.37 \pm 0.10 / \\
0.52 \pm 0.03\end{array}$ \\
\hline \multicolumn{11}{|c|}{ Shannon's evenness index (J) / Simpson's evenness index (E) } \\
\hline $\begin{array}{c}0.80 / \\
0.64\end{array}$ & $\begin{array}{l}0.71 / \\
0.49\end{array}$ & $0.92 / 0.55$ & $\begin{array}{c}0.81 \pm 0.04 / \\
0.56 \pm 0.04\end{array}$ & $\begin{array}{c}0.97 / \\
1.04\end{array}$ & $0.81 / 1.33$ & $\begin{array}{c}0.89 \pm 0.08 / \\
1.18 \pm 0.15\end{array}$ & $\begin{array}{l}0.79 / \\
0.43\end{array}$ & $0.65 / 0.51$ & $\begin{array}{c}0.77 / \\
0.68\end{array}$ & $\begin{array}{c}0.74 \pm 0.04 / \\
0.54 \pm 0.07\end{array}$ \\
\hline \multicolumn{11}{|c|}{ Simpson's dominance index (C) } \\
\hline 0.48 & 0.49 & 0.39 & $0.45 \pm 0.03$ & 0.52 & 0.39 & $0.45 \pm 0.07$ & 0.42 & 0.51 & 0.51 & $0.48 \pm 0.03$ \\
\hline \multicolumn{11}{|c|}{ Index of elastic sustainability (UU) / Index of resistance sustainability (UR) } \\
\hline $\begin{array}{c}2.05 / \\
1.52 \\
\end{array}$ & $\begin{array}{l}1.97 / \\
1.05 \\
\end{array}$ & $3.52 / 1.59$ & $\begin{array}{c}2.51 \pm 0.50 / \\
1.39 \pm 0.17\end{array}$ & $\begin{array}{l}1.60 / \\
1.49 \\
\end{array}$ & $0.85 / 1.05$ & $\begin{array}{c}1.23 \pm 0.38 / \\
1.27 \pm 0.22 \\
\end{array}$ & $\begin{array}{l}2.92 / \\
1.13 \\
\end{array}$ & $1.69 / 1.27$ & $\begin{array}{c}1.74 / \\
1.19 \\
\end{array}$ & $\begin{array}{c}2.12 \pm 0.40 / \\
1.20 \pm 0.04 \\
\end{array}$ \\
\hline \multicolumn{11}{|c|}{ Index of general sustainability (U) } \\
\hline 3.57 & 3.02 & 5.11 & $3.90 \pm 0.63$ & 3.09 & 1.90 & $2.49 \pm 0.60$ & 4.05 & 2.96 & 2.93 & $3.31 \pm 0.37$ \\
\hline
\end{tabular}

Note: $\mathrm{M}$ is the arithmetic average of the index for the study area; $\mathrm{m}$ is the error of the arithmetic mean value.

Table 3. Diversity indices of small mammal communities in different geographical areas of Kamchatka

\begin{tabular}{|l|l|l|l|l|l|l|l|}
\hline Indices & $\begin{array}{l}\text { Lake } \\
\text { Talovskoye }\end{array}$ & $\begin{array}{l}\text { River } \\
\text { Tylakrylvayam }\end{array}$ & $\begin{array}{l}\text { River } \\
\text { Ichiginnyvayam }\end{array}$ & $\begin{array}{l}\text { Geysernaya Riv- } \\
\text { er valley (accord- } \\
\text { ing to 2013-2016 } \\
\text { survey) }\end{array}$ & $\begin{array}{l}\text { caldera (accord- } \\
\text { ing to 2014-2015 } \\
\text { survey) }\end{array}$ & $\begin{array}{l}\text { The foot of the } \\
\text { Kikhpinich vol- } \\
\text { cano (according } \\
\text { to 2016 survey) }\end{array}$ & $\begin{array}{l}\text { Lake Kuryl shore } \\
\text { (according to } \\
2015 \text { survey) }\end{array}$ \\
\hline $\mathrm{H}$ & $1.38 \pm 0.05$ & $0.89 \pm 0.08$ & $1.37 \pm 0.10$ & 1.2 & 1.53 & 0.92 & 1.15 \\
\hline $\mathrm{D}$ & $0.55 \pm 0.03$ & $0.43 \pm 0.05$ & $0.52 \pm 0.03$ & 0.48 & 0.6 & 0.44 & 0.45 \\
\hline $\mathrm{J}$ & $0.81 \pm 0.04$ & $0.89 \pm 0.08$ & $0.74 \pm 0.04$ & 0.76 & 0.76 & 0.92 & 0.72 \\
\hline $\mathrm{E}$ & $0.45 \pm 0.04$ & $0.45 \pm 0.15$ & $0.48 \pm 0.03$ & 0.7 & 0.42 & 1.13 & 0.74 \\
\hline
\end{tabular}


Table 4. Integral indices of the small mammal communities on the surveyed sites in Parapolsky Dol

\begin{tabular}{|c|c|c|c|c|c|c|c|}
\hline \multicolumn{3}{|c|}{ Lake Talovskoye shore } & \multicolumn{2}{|c|}{ Tylakrylvayam River floodplain } & \multicolumn{3}{|c|}{ Ichiginnyvayam River floodplain } \\
\hline $\begin{array}{l}\Xi \\
\text { ص } \\
\pm \\
0\end{array}$ & 乞 & 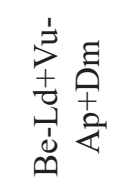 & $\begin{array}{l}\Xi \\
\text { m } \\
\pm \\
\text { م. }\end{array}$ & 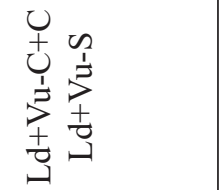 & 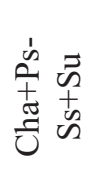 & 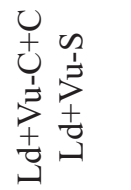 & $\begin{array}{l}D_{1} \\
\stackrel{1}{\mid} \\
\text { ص }\end{array}$ \\
\hline \multicolumn{8}{|c|}{ Number of females } \\
\hline 11 & 3 & 4 & 1 & 0 & 3 & 23 & 5 \\
\hline \multicolumn{8}{|c|}{ Number of pregnant females } \\
\hline 7 & 1 & 2 & 1 & 0 & 0 & 8 & 2 \\
\hline \multicolumn{8}{|c|}{ Number of embryos } \\
\hline 42 & 8 & 11 & 6 & 0 & 0 & 77 & 21 \\
\hline \multicolumn{8}{|c|}{ Number of resorbed embryos } \\
\hline 2 & 0 & 0 & 0 & 0 & 0 & 0 & 0 \\
\hline \multicolumn{8}{|c|}{ Number of wintering animals } \\
\hline 4 & 0 & 2 & 3 & 3 & 0 & 6 & 1 \\
\hline \multicolumn{8}{|c|}{ Index of reproductive success (URZ) } \\
\hline 6060.61 & 3333.33 & 4999.99 & 9999.99 & 0 & 0 & 3478.26 & 3999.99 \\
\hline \multicolumn{8}{|c|}{ Conservation index (IKV) } \\
\hline 0.79 & 0.25 & 0.5 & 0.80 & 0.75 & 0.60 & 0.71 & 0.67 \\
\hline \multicolumn{8}{|c|}{ Generalised index of well-being (SSS) } \\
\hline 65.43 & 65.43 & 56.77 & 105.68 & 3.59 & 6.62 & 61.84 & 45.71 \\
\hline
\end{tabular}

The highest proportion of pregnant females, maximum relative fertility including resorbed embryos and the highest reproductive success indices were recorded in the small mammal communities of ribbon floodplain cedar and birch forests $(\mathrm{Pp}+\mathrm{Bm})$ on the shore of Lake Talovskoye and in the floodplain of the River Tylakrylvayam, located on the highland (Table 4).

No reproduction was observed in the low floodplain habitats (Cha+Ps-Ss $+\mathrm{Su}$ in the River Ichiginnyvayam floodplain; $\mathrm{Ld}+\mathrm{Vu}-\mathrm{C}+\mathrm{C}$; $\mathrm{Ld}+\mathrm{Vu}-\mathrm{S}$ in the River Tylakrylvayam floodplain). These habitats are therefore characterised by zero reproductive success and low values of well-being index (SSS).

\section{Species composition}

The species of voles and shrews are described as common in most regions of north-eastern Russia: the northern part of the Far East (Yudin et al., 1976), the extreme north east of Siberia (Chernyavskiy, 1984), northeastern Siberia (Volpert \& Shadrina, 2002), the mainland shore of the Okhotsk Sea (Dokuchaev, 2012), the floodplain of the middle reaches of the River Ichiginnyvayam (Kazansky \& Sedash, 2015), as well as a number of other northern regions of Eurasia from Fennoscandia to West Siberia (Henttonen \& Wallgren, 2001; Bobretsov \& Simakin, 2015; Bykova et al., 2015; Kataev, 2015, 2017).

Kazansky \& Sedash (2015) registered the transpalaearctic species Microtus oeconomus, which is not identified by any of the censuring methods in our study. This can be accounted by the fact that during the period of our survey the number of $M$. oeconomus was considerably lower. Significant differences in the abundance of $M$. oeconomus and species of the Myodes genus are easily explained by differences in their ecology, and, accordingly, the different stages of their population cycles.

Nikanorov (2000) considers Ochotona hyperborea to be common for Kamchatka with sporadic distribution in mountainous areas on large-slaked turfy fields and old lavas. This species is found in similar habitats of South Yakutia (Pogulyaeva, 2003).

The identified animal species belong to the genera Myodes Pallas, 1811, Sorex Linnaeus, 1758, Ochoto$n a$, common to Kamchatka and North America.

Myodes rutilus, a trans-holarctic species, is found in the boreal zone of Eurasia and North America (Gashev, 2000; Smith \& Zollner, 2001; Boonstra et al., 2001; Krebs et al., 2014; Ivanter \& Moiseeva, 2015; Agulova et al., 2016; Sullivan et al., 2017). According to morphological (Nikanorov, 2000) and genetic studies (Frisman et al., 2016), populations of $M$. rutilus in Kamchatka belong to the subspecies Myodes rutilus jochelsoni $\mathrm{G}$. Allen, 1903, and by the variability of the mitochondrial «cytb» gene are included in the North American (Beringian) group (Pereverzeva et al., 2013). The rest of the registered species are Eurasian.

The total abundance of small mammals in the River Ichiginnyvayam floodplain is only slightly low- 
er than the value noted by Kazansky \& Sedash (2015) for the first decade of November 2013. At the same time, the abundance of separate species from 2013 to 2017 varies in different directions (Table 1). Multidirectional changes in the numbers of closely related species of Myodes rutilus and M. rufocanus indicate a competitive relationship between them. This is an indicator of low resource capacity of the habitats. The number of Sorex caecutiens and S. isodon changes in one direction, which indicates the absence of interspecific competition, and can be explained by the low number of $S$. isodon in the north of Kamchatka.

The high abundance values for Sorex caecutiens captured by cylinders reflects the biological peculiarity of small shrews, which are not captured easily into snap traps. But due to the high metabolic rate, they are constantly forced to move around the territory in search of food and fall into the cylinders.

According to the research data, the numerical prevalence of $S$. caecutiens over $S$. isodon and the numerical ratio of different species that we observed are typical for the north of Kamchatka (Yudin et al., 1976; Kazansky \& Sedash, 2015).

The small number of identified species and the numerical dominance of one or two species (Myodes rutilus, Sorex caecutiens) are determined by the low resource capacity of the habitats due to a number of natural and climatic features (negative average annual temperature, high humidification coefficient, short summer), which make animals' living conditions very difficult in the study area.

\section{Community structure}

We compared the obtained results with the data of Bykova et al. (2015), who studied the diversity and resilience of the communities of small mammal in different structural and functional zones of Novy Urengoy town, located in the forest-tundra zone (West Siberia, Tyumen region, 66.083 N, 76.633 E). It showed that the species diversity indices of small mammal communities of the Parapolsky Dol have intermediate values between those of the disturbed habitat communities of Novy Urengoy (multistorey building zone: $\mathrm{H}=0.72, \mathrm{D}=0.32$; urban zone: $\mathrm{H}=1.66, \mathrm{D}=0.62)$, and significantly lower than those of the community in parkland zone $(\mathrm{H}=2.37$, $\mathrm{D}=0.78)$ and suburban zone $(\mathrm{H}=3.16, \mathrm{D}=0.82)$.

The results of the comparison confirm the severity of the climatic conditions of northern Koryakia for small mammals and the vulnerability of the Parapolsky Dol ecosystems.

The comparison of the small mammal communities in Parapolsky Dol and Tai National Park (West
Africa; equatorial forest zone; $5.65 \mathrm{~N}, 7.133 \mathrm{E}$ according to Akpatou et al., 2018) by Margalef's (R) species richness indices and Shannon's species diversity $(\mathrm{H})$ showed that the maximum values of the first mentioned index (Table 2) are significantly inferior to those of the communities of secondary forests $(\mathrm{R}=15 ; \mathrm{H}=$ 2.12) and virgin forests $(\mathrm{R}=10 ; \mathrm{H}=1.79)$ of the Tai National Park. However, the Shannon's species diversity index of the small mammal communities on the Lake Talovskoye shore and the River Ichiginnyvayam floodplains is comparable to that of bog forests $(\mathrm{R}=8$; $\mathrm{H}=1.4$ ), despite the significantly lower species richness. Thus, the general geo-ecological determinant of the biological diversity of the small mammal communities in Parapolsky Dol and Tai National Park is the degree of watering (swampiness) of the study area.

It is noteworthy that general sustainability of the small mammal communities is determined to a greater degree by the elastic sustainability, which is normal for mature natural ecosystems (Table 2) (Gashev et al., 2015). The increase in the elastic component with growing «maturity» of natural or man-made habitats demonstrates the dynamics of sustainability indices as we move from the most transformed habitats in the Novy Urengoy centre to its periphery: multi-storey building zone $-\mathrm{UR}=0.99, \mathrm{UU}=0.27, \mathrm{U}=1.26$; urban inarable zone $-\mathrm{UR}=1.18, \mathrm{UU}=1.22, \mathrm{U}=2.40$; forest park zone $-\mathrm{UR}=1.21$, $\mathrm{UU}=3.25, \mathrm{U}=4.47$; suburban area $-\mathrm{UR}=1.30, \mathrm{UU}=5.43, \mathrm{U}=6.3$ (Bykova et al., 2015). The growth of resistant sustainability in the course of primary plant succession reflects a number of changes in the indices of sustainability in the small mammal communities in the River Geysernaya valley towards habitats farther from geothermal sources. The good examples were forbs around thermal sites in the central part of the River Geysernaya valley $\mathrm{UR}=0.31, \mathrm{UU}=1.02, \mathrm{U}=1.33$; stonegrass forbs on the highland $-\mathrm{UR}=0.44, \mathrm{UU}=1.24, \mathrm{U}=1.68$; fern alder on the highland $-\mathrm{UR}=0.68, \mathrm{UU}=1.61, \mathrm{U}=2.39$. Obviously, the general sustainability of the small mammal communities in Parapolsky Dol is lower than the general sustainability in less transformed and natural habitats of the forest-tundra zone of West Siberia, but higher than in the River Geysernaya valley, an area of increased geothermal and volcanic activity.

The value of anthropogenic adaptability index in small mammal communities of the Parapolsky Dol fully corresponds to our survey of the small mammal communities in Protected Areas of central and southern Kamchatka carried out from 2013 to 2016. This value is by 1-2 degrees lower than IAA for small mammal communities in different zones of Novy Urengoy (multi-storey buildings zone 
and urban inarable zone $-\mathrm{IAA}=100$; forest park zone $-\mathrm{IAA}=20.2$; suburban forest - IAA $=6.13$ ) (Bykova et al., 2015). The results indicate that the ecosystems of Parapolsky Dol are intact.

In general, the structure of the small mammal communities in the study areas of Parapolsky Dol is similar to the structure of the communities studied in 2013-2016 in the River Geysernaya valley, the Uzon volcano caldera (Kronotsky State Nature Biosphere Reserve) and the vicinity of the River Ozernaya (Lake Kurilskoye, South Kamchatka Sanctuary) (Levykh, 2017).

\section{Demographic characteristics of communities}

Higher values of the reproductive success index are observed in the small mammal communities of the floodplain cedar and birch forests $(\mathrm{Pp}+\mathrm{Bm})$ on the Lake Talovskoye shores and in the River Tylakrylvayam floodplain. On the one hand, this is consistent with the low rates of general abundance and abundance of certain species in these areas, since it is known that late reproduction is characteristic of small mammal populations in the growth phase. On the other hand, it complies with the highest values of conservation index (IKV: Talovskoye -0.79 , Tylakrylvayam -0.80 ), and the generalised index of well-being (SSS: Talovskoye -65.43 , Tylakrylvayam - 105.68) in these habitats, which can be considered as breeding stations or sources and regarded as key habitats for protection.

At the same time, the actual sampling size of small mammals in the River Tylakrylvayam floodplain is very small as only one pregnant female was captured. Therefore, the high reproductive success in the mentioned community without additional research should be considered only as a tendency.

The communities in the floodplain habitats have zero indices of reproductive success and very low $\mathrm{SSS}$ values (Cha+Ps-Ss+Su in the River Ichiginnyvayam floodplain; $\mathrm{Ld}+\mathrm{Vu}-\mathrm{C}+\mathrm{C}$; $\mathrm{Ld}+\mathrm{Vu}-\mathrm{S}$ in the River Tylakrylvayam floodplain) and, therefore, can be considered sink habitats. This is corroborated by the sex and age structure of the populations of separate species, which determines the demographic structure of communities in general. For instance, in the $\mathrm{Cha}+\mathrm{Ps}-\mathrm{Ss}+\mathrm{Su}$ habitat (River Ichiginnyvayam floodplain) three of the four registered species (Myodes rutilus, M. rufocanus, Sorex isodon) were males, we captured only one young female specimen of Sorex caecutiens without indications of breeding. Of the two identified species from the River Tylakrylvayam floodplain (Myodes rutilus and Sorex caecutiens) only males were recorded in the habitats $\mathrm{Ld}+\mathrm{Vu}-\mathrm{C}+\mathrm{C}$ and $\mathrm{Ld}+\mathrm{Vu}-\mathrm{S}$.
Small mammal communities in most of the surveyed habitats are characterised by higher SSS values compared to urban communities in a similar climatic zone (Novy Urengoy: multi-storey building zone $-\mathrm{S}=35.02$; urban zone $-\mathrm{S}=26.68$; forest park area $-\mathrm{S}=14.16$; suburban forest $-\mathrm{S}=10.50$ ) (Bykova et al., 2015).

\section{Conclusions}

In the surveyed habitats of Parapolsky Dol we captured several specimens of five small mammal species common for Northern Kamchatka, such as Insectivora - Sorex isodon, S. caecutiens, Rodentia - Myodes rutilus, M. rufocanus, and the stenotopic species Lagomorpha - Ochotona hyperborea, restricted to kurumnik.

By using snap traps in all study areas, we revealed the numerical dominance of Myodes rutilus in most habitats, co-dominated by Sorex caecutiens and M. rufocanus. According to the results of counting by cylinders, $S$. caecutiens is the absolute dominant in the open habitats. Such dominance structure is characteristic of the small mammal communities in the north of the Far East. An important natural factor determining the spatial distribution and abundance of small mammals is the degree of swampiness of an area.

The small mammal communities in Parapolsky Dol are characterised by low diversity indices, average values of dominance index and rather high evenness due to the harsh natural landscape features of the territory. The diversity/evenness structure in all the communities corresponds to that of the natural habitats of central, southern Kamchatka and Siberia. But it varies in different study areas depending on the landscape features, the diversity of biotopes and the phases of the population cycles of the species belonging to a community.

General sustainability of the small mammal communities is determined to a greater degree by elastic sustainability, which is typical of mature natural ecosystems. And this exceeds the sustainability in the habitats of the East Kamchatka mountain belt (River Geysernaya valley) in the area of increased geothermal and volcanic activity. Low indices of anthropogenic adaptation and relatively high generalised indices of well-being in the small mammal communities support the conclusion about the undisturbed condition of Parapolsky Dol ecosystems.

Relatively high diversity and sustainability indices are characteristic of the communities in particular habitats and, in general, for the small mammal community on the Lake Talovskoye shore. This allows us to con- 
sider the Lake Talovskoye shore as a key area for the study and conservation of biodiversity.

Cedar and birch floodplain forests (Pinus pumila + Betula middendorffii) as source habitats, or survival and breeding stations, are important areas for biodiversity protection. This is confirmed by relatively high values of conservation, reproductive success and wellbeing indices in the small mammal communities.

\section{Acknowledgements}

The authors express their deep gratitude to the staff of Kronotsky State Nature Reserve (Russia), especially to Darya M. Panicheva (Deputy Director in Science) and Fedor V. Kazansky (Senior Researcher) for the organisation of the expedition and assistance in conducting field research, also to the inspectors of Koryak State Nature Reserve A. N. Sorokin and I. G. Podgorny for their help in the field study.

\section{References}

Aars J., Ims R.A. 2002. Intrinsic and climatic determinants of population demography: the winter dynamics of tundra voles. Ecology 83(12): 3449-3456. DOI: 10.1890/0012-9658(2002)083[3449:IACDOP]2.0.CO;2

Agulova L.P., Moskvitina N.S., Bolshakova N.P., Kravchenko L.B., Ivanova N.V., Romanenko V.N. 2016. Longterm Dynamics and Correlations of Ecophysiological Parameters in Murine Rodent Communities. Russian Journal of Ecology 47(5): 460-466. DOI: 10.7868/ S036705971604003X

Akpatou B.K., Bohoussou K.H., Kadjo B., Nicolas V. 2018. Terrestrial small mammal diversity and abundance in Taï National Park, Côte d'Ivoire. Nature Conservation Research 3(Suppl.2): 66-75. DOI: 10.24189/ncr.2018.067

Averin Yu.V. 2013. Terrestrial Invertebrates of Eastern Kamchatka. Proceedings of Kronotsky State Nature Biospheric Reserve 1: 1-259. [In Russian]

Begon M., Harper J.L., Townsend C.R. 1989. Ecology: Individuals, Populations and Communities. Vol. 2. Moscow: Mir. 477 p. [In Russian]

Beldiman L.N., Kuzmina E.Yu., Neshataev V.Yu. 2017. Coenotic characteristics of the moss component of elfinwood and shrub communities of the protected and anthropogenically disturbed territories (Northern Koryakia, Kamchatka Territory). Rastitelnye Resursy 53(3): 403-424. [In Russian]

Bobretsov A.V., Petrov A.N., Lukyanova L.E., Bykhovets N.M. 2015. Structural adjustment of the population of forest voles (Clethrionomys, Rodentia) in the foothills of the Northern Urals. Zoologicheskii Zhurnal 94(6): 731738. DOI: 10.7868/S0044513415060070 [In Russian]

Bobretsov A.V., Simakin L.V. 2015. Peculiar Features of Small Mammal Community Structure on Different Macroslopes of the Northern Urals. Russian Journal of Ecology 46(5): 470-475. DOI: 10.7868/S0367059715050066

Boonstra R., Krebs C.J., Gilbert S., Schweiger S. 2001. Voles and mice. In: C.J. Krebs, S. Boutin, R. Boonstra (Eds.): Ecosystem dynamics of the boreal forest - the Kluane project. New York: Oxford University Press. P. 215-239.
Bykova E.A., Gashev S.N., Levykh A.Yu. 2015. Natural and historical aspects of the origin and functioning of urban mammals in West Siberia, Russia and Uzbekistan. Acta Biologica Universitatis Daugavpiliensis 15(1): 47-64.

Cadieux M.-C., Fauteux D., Gauthier G. 2015. Technical manual for sampling small mammals in the Arctic. Version 1. Quebec: Centre d'étudesnordiques, Université Laval. 55 p.

Chernyavskiy F.Yu. 1984. Mammals of Extreme North-East of Siberia. Moscow: Nauka. 387 p. [In Russian]

Deitloff J., Falcy M.R., Krenz J.D., McMillan B.R. 2010. Correlating Small Mammal Abundance to Climatic Variation over Twenty Years. Journal of Mammalogy 91(1): 193-199. DOI: 10.1644/08-MAMM-A-267R.1

Dokuchaev N.E. 1997. Role of Beringian land and in expansion and development of new forms of common shrews. Vestnik of the Far East Branch of RAS 2: 54 61. [In Russian]

Dokuchaev N.E. 2012. Sorricids (Soricomorpha) and Rodents (Rodentia) distribution peculiarities at continental shore of the Okhotsk Sea. Bulletin of the North-East Scientific Centre of RAS 3: 118-123. [In Russian]

Frisman L.V., Kartavtseva I.V., Pavlenko M.V., Kapitonova L.V. 2016. Genogeographic variability of haemoglobin in the red vole (Myodes rutilus Pallas, 1779) in the south of the Russian Far East. Regional Problems 19(3): 123-130. [In Russian]

Gashev S.N. 2000. Mammals in the ecological monitoring system (Tyumen Region). Tyumen: Tyumen State University. 220 p. [In Russian]

Gashev S.N. 2001. Elastic Sustainability of Ecological Systems. Contemporary Problems of Ecology 8(5): 645650. [In Russian]

Gashev S.N., Bykova E.A., Levykh A.Yu. 2015. Resilience of small mammalian urbenoza communities in various natural zones. Proceedings of the Samara Scientific Centre of RAS 17(6): 14-18. [In Russian]

Gashev S.N., Aleshina O.A., Lupinos M.Y., Mardonova L.B., Mitropolskiy M.G., Selyukov A.G., Sorokina N.V., Stolbov V.A., Shapovalov S.I., Zuban I.A. 2017. Holocene Faunal Trends in West Siberia and Their Causes. Izvestiya Atmospheric and Oceanic Physics 53(8): 791803. DOI: 10.1134/S0001433817080059 [In Russian]

Henttonen H., Wallgren H. 2001. Small rodent dynamics and communities in the birch forest zone of northern Fennoscandia. In: F.E. Wielgolaski (Ed.): Nordic Mountain Birch Ecosystems. Man and the Biosphere Series. Vol. 27. New York and London: UNESCO, Paris and Parthenon Publishing Group. P. 261-278.

Hope A.G., Waltari E., Morse N.R., Cook J.A., Flamme M.J., Talbot S.L. 2017. Small mammals as indicators of climate, biodiversity, and ecosystem change. Alaska Park Science 16(1). Available from https://www.nps.gov/articles/aps-16-1-16.htm

Istomin A.V. 2009. Some Biotic Reactions to Climate Change in the Forest Landscape of the Caspian-Baltic Watershed. IKBFU's Vestnik. Series Natural and Medical Sciences 7: 15-22. [In Russian]

Ivanter E.V., Korosov A.V. 2013. Elementary biometrics: a study guide. Petrozavodsk: Publishing House of PetrSU. 110 p. [In Russian] 
Ivanter E.V., Moiseeva E.A. 2015. On the ecology of the red vole (Clethrionomys rutilus Pall.) in the south-western periphery of the range. Transactions of KarRC RAS. Ecological Studies Series 1: 37-47. DOI: 10.17076/eco44 [In Russian]

Karaseva E.V., Telitsyna A.Yu., Zhigalsky O.A. 2008. Methods for the study of rodents in the field. Moscow: LCI Publishing House. 416 p. [In Russian]

Kataev G.D. 2015. Monitoring of populations of small mammals micromammalia in north taiga of Fennoscandia. Bulletin of the Moscow Society of Naturalists. Biological Series 120(3): 3-13. [In Russian]

Kataev G.D. 2016. Long-term (1936-2016) monitoring of the species composition and population of small mammals in the north Lapland taiga. Bulletin of the Moscow Society of Naturalists. Biological Series 121(6): 3-17. [In Russian]

Kataev G.D. 2017. The impact of industrial emissions of copper-nickel smelter complex on the status of populations and communities of small mammals in the Kola Peninsula. Nature Conservation Research 2(Suppl. 2): 19-27. DOI: 10.24189/ncr.2017.033 [In Russian]

Kazansky F.V., Sedash G.A. 2015. Fauna of small mammals in the vicinity of Parapolsky Dol. The results ofthe census carried out in October-November, 2013 in the middle reaches of the Ichiginnyvajam River (the Koryak Region). In: Kamchatka and Adjacent Seas Biodiversity Conservation. Petropavlovsk-Kamchatsky: Kamchatpress. P. 61-64. [In Russian]

Krebs C.J., Boonstra R., Boutin S., Sinclair A.R.E., Smith J.N.M., Gilbert B.S., Martin K., O’Donoghue M., Turgington R. 2014. Trophic dynamics of the boreal forests of the Kluane region. Arctic 67(5): 71-81. DOI: 10.14430/arctic4350

Kryazhimskii F.V., Bolshakov V.N., Koryukin V.I. 2001. Man in the Light of Current Ecological Problems. Russian Journal of Ecology 32(6): 369-374. DOI: 1023/A:1012531414462

Levykh A.Yu. 2017. Small mammals in biomonitoring of the Geysernaya River ecosystems. Proceedings of Kronotsky Nature Reserve 5: 39-54. [In Russian]

Litvinov Yu.N. 2008. Micoprocesses of community evolutiuon (on the example of small mammal communities). Vestnik of Irkutsk State Academy of Agriculture 30: 2946. [In Russian]

Magarran E. 1992. Ecological diversity and its measurement. Moscow: Mir. 184 p. [In Russian]

Martell A.M., Pearson A.M. 1978. The small mammals of the Mackenzie delta region, Northwest Territories, Canada. Arctic 31(4): 475-488. DOI: 10.14430/arctic2674

Moskvitina N.S., Kravchenko L.B., Suchkova N.G. 2000. Time Course of European Red Vole (Clethrionomys glareolus Schreber) Populations in the Eastern Periphery of the Areal. Contemporary Problems of Ecology 3: 373-382. [In Russian]

Myers P., Lundrigan B.L., Hoffman S.M.G., Haraminac A.P., Seto S.H. 2009. Climate-induced changes in the small mammal communities of the Northern Great Lakes Region. Global Change Biology 15(6): 1434-1454. DOI: 10.1111/j.1365-2486.2009.01846.x

Neshataev V.Yu., Neshataeva V.Yu., Yakubov V.V. 2017. Vegetation of water area and shore of Lake Talovskoye and its vicinities (Koryak Area, the Kamchatka Territory). Vegetation of Russia 31: 59-76. [In Russian]
Nikanorov A.P. 2000. Cass Mammalia - Mammals. In: R.S. Moiseev, A.M. Tokranov: Catalog of Vertebrates of Kamchatka and Adjacent Waters. Petropavlovsk-Kamchatsky: Kamchatskiy Petchatniy Dvor. P. 100-111. [In Russian]

Odum Yu. 1986. Ecology. Moscow: Mir. Vol. 1. 328 p. [In Russian]

Ovaskainen O., Skorokhodova S., Yakovleva M., Sukhov A., Kutenkov A., Kutenkova N., Shcherbakov A., Meyke E., Delgado M.D.M. 2013. Community-level phenological response to climate change. Proceedings of the National Academy of Sciences of the United States of America 110(33): 13434-13439. DOI: 10.1073/pnas.1305533110

Pavlinov I.Ya. 2002. Brief guide of land animals of Russia. Moscow: Publishing House of Moscow State University. 167 p. [In Russian]

Pereverzeva V.V., Primak A.A., Dubinin E.A. 2013. Phylogenetic relations of the red vole populations of Myodes (=Clethrionomys) rutilus Pallas, 1779 of the Northern Prihotsk region and the Kolyma region. Vavilov Journal of Genetics and Breeding 17(3): 444-451. [In Russian]

Pogulyaeva I.A. 2003. To the winter feeding of the northern pikas (Ochotona hyperborean Pallas, 1811) of the Aldan basin. Contemporary Problems of Ecology 10(5): 641-644. [In Russian]

Prokopiev E.P. 2003. Ecology of plant communities (phytocenology). Tomsk: Tomsk State University. 456 p. [In Russian]

Schwartz S.S., Smirnov VS, Dobrinsky L.N. 1968. The method of morphophysiological indicators in the ecology of terrestrial vertebrates. Sverdlovsk. 387 p. [In Russian]

Smith W.P., Zollner P.A. 2001. Seasonal Habitat Distribution Of Swamp Rabbits, White-Tailed Deer, and Small Mammals in Old Growth and Managed Bottomland Hardwood Forests. In: Gen. Tech. Rep. SRS 42. Asheville, NC: U.S. Department of Agriculture, Forest Service, Southern Research Station. P. 83-98.

Sullivan T.P., Sullivan D.S., Sullivan J.H. 2017. Mammalian responses to windrows of woody debris on clearcuts: Abundance and diversity of forest-floor small mammals and presence of small mustelids. Forest Ecology and Management 399: 143-154. DOI: 10.1016/j.foreco.2017.05.028

Vinogradov V.V. 2009. Long-term dynamics of mouselike rodents population size in dark coniferous forest of the East Sayan mountains. Russian Journal of Theriology 8(2): 97-106. [In Russian]

Volpert Ya.L., Shadrina E.G. 2002. Small Mammals of Siberian North-West. Novosibirsk: Nauka. 246 p. [In Russian]

Weksler M., Lanier H.C., Olson L.E. 2010. Eastern Beringian biogeography: historical and spatial genetic structure of singing voles in Alaska. Journal of Biogeography 37(8): 1414-1431. DOI: 10.1111/j.1365-2699.2010.02310.x

Yudin B.S. 1971. Insectivorous mammals of Siberia. Moscow: Nauka. 170 p. [In Russian]

Yudin B.S., Krivosheev V.G., Belyaev V.G. 1976. Small Mammals of the North of Far East. Novosibirsk: Nauka. 270 p. [In Russian]

Zakharov V.M., Sheftel B.I., Dmitriev S.G. 2011. Climate Change and Population Dynamics: Possible Consequences (with Particular References to Study of Small Mammals in Central Siberia). Uspekhi Sovremennoi Biologii 131(5): 435-439. [In Russian] 
Appendix. Abbreviations used in the text

\begin{tabular}{|c|c|c|}
\hline № & Abbreviation & Meaning \\
\hline 1 & UBS & proportion of pregnant females \\
\hline 2 & EMS & number of embryos per one pregnant female \\
\hline 3 & URE & proportion of resorbed embryos \\
\hline 5 & IKV & conservation index \\
\hline 6 & SSS & generalised index of community well-being \\
\hline 7 & IAA & index of anthropogenic adaptability \\
\hline 8 & $\mathrm{U}$ & general sustainability \\
\hline 9 & UU & elastic sustainability \\
\hline 10 & UR & resistant sustainability \\
\hline 11 & $\mathrm{R}$ & Margalef's species richness index \\
\hline 12 & $\mathrm{D}$ & Simpson's diversity index \\
\hline 13 & $\mathrm{H}$ & Shannon's diversity index \\
\hline 14 & $\mathrm{~J}$ & Shannon's evenness index \\
\hline 15 & $\mathrm{E}$ & Simpson's evenness index \\
\hline 16 & $\mathrm{~V}$ & number of genera \\
\hline 17 & $\mathrm{~N}$ & total number of species \\
\hline 19 & $\mathrm{~K}$ & ratio of «viscosity» of the medium \\
\hline 20 & $\mathrm{G}$ & ratio of «elasticity» of the medium \\
\hline
\end{tabular}

\title{
ВИДОВОЙ СОСТАВ И СТРУКТУРА СООБЩЕСТВ МЕЛКИХ МЛЕКОПИТАЮЩИХ ПАРАПОЛЬСКОГО ДОЛА (ГОСУДАРСТВЕННЫЙ ЗАПОВЕДНИК «КОРЯКСКИЙ», КАМЧАТКА)
}

\author{
А. Ю. Левых, В. В. Панин
}

\author{
Тюменский государственный университет, Россия \\ e-mail:aljurlev@mail.ru,paninvv@mail.ru
}

Парапольский дол принадлежит к крупнейшим водно-болотным угодьям всемирного значения, однако труднодоступность данной территории обусловливает наличие лишь фрагментарных сведений о видовом составе и структуре сообществ животных. Это обосновывает актуальность изучения индикаторной группы - мелких млекопитающих. В работе приведены результаты предварительного исследования фауны и структуры сообществ мелких млекопитающих Парапольского кластерного участка Государственного заповедника «Корякский», проведённого с 25 августа 2017 г. по 15 сентября 2017 г. На обследованных участках (на побережье озера Таловское, в пойме реки Тылакрылваям, в пойме реки Ичигиннываям) отработано 2735 ловушко-суток (лов.-сут.), 144 цилиндро-суток (цил.-сут.) и отловлено пять видов мелких млекопитающих: Myodes rutilus, M. rufocanus, Sorex isodon, S. caecutiens, Ochotona hyperborea. Обследованные местообитания образуют следующий ряд в направлении снижения обилия мелких млекопитающих: пойма р. Ичигиннываям - 10.9 экз./100 лов.-сут., 8.0 экз./100 цил.-сут.; побережье озера Таловское - 3.48 экз./100 лов.-сут.; пойма р. Тылакрылваям - 1.43 экз./100 лов.-сут., 2.53 экз./100 цил.-сут. . Наибольшее количество видов (4) отловлено в местообитаниях с древесной растительностью и ягодными кустарничками. По результатам учёта ловушками Геро выявлена тенденция численного доминирования в большинстве местообитаний $M$. rutilus, содоминирования - S. caecutiens и M. rufocanus. По результатам учёта цилиндрами абсолютным доминантом в обследованных открытых местообитаниях является S. caecutiens. Все исследуемые сообщества характеризуются невысокими индексами разнообразия, средними значениями индекса доминирования, достаточно высокой выравненностью и низкой устойчивостью. Такая структура сообществ мелких млекопитающих объясняется зонально-климатическими условиями территории. Структура разнообразиявыравненности всех сообществ соответствует таковой естественных местообитаний центральной, южной Камчатки и Сибири. Сообщества мелких млекопитающих объединённых местообитаний побережья озера Таловское и поймы реки Ичигиннываям отличаются большими индексами разнообразия, а сообщества поймы реки Тылакрылваям - большим индексом выравненности. В период исследований в сообществах мелких млекопитающих наблюдалось позднее размножение (отловлены беременные и кормящие самки разных возрастных групп). Наибольшее количество беременных самок, эмбрионов и самые высокие показатели успешности размножения, индексы консервативности и обобщённые показатели благополучия отмечены в сообществах мелких млекопитающих ленточных пойменных кедрово-берёзовых лесов на побережье оз. Таловское и в пойме р. Тылакрылваям. В растительных ассоциациях Ledum decumbens + Vaccinium uliginosum - Cladonia sp. + Cladina sp. и Ledum decumbens + Vaccinium uliginosum - Sphagnum sp. размножение не наблюдалось. Материалы данной работы дополняют сведения о фауне и структуре сообществ мелких млекопитающих Парапольского дола.

Ключевые слова: берингийская лесотундра, бурозубки, видовое разнообразие, землеройки, мелкие наземные грызуны, относительное обилие 